\title{
PENINGKATAN HASIL BELAJAR SISWA SEKOLAH DASAR PADA MATA PELAJARAN IPA DENGAN PENDEKATAN KETERAMPILAN PROSES SAINS
}

\author{
${ }^{1}$ Nurani Hadnistia Darmawan \\ 1PGSD STKIP Bina Mutiara Sukabumi \\ 1nhalfaruq@gmail.com \\ 2Hilman Hilmawan \\ 2PGSD STKIP Bina Mutiara Sukabumi \\ hilmanh99@gmail.com
}

\begin{abstract}
This research is motivated because the problem of student learning result of fourth grade of SDN Pangestu on science subjects which tend to be low. Though science subjects in elementary school is one of the subjects listed in the primary school curriculum. Science subjects are also subjects that must be tested at the end of school examination (UAS). In the learning process, to optimize student learning outcomes, the teacher must optimize the skills of the science process. This study aims to determine the improvement of student learning outcomes in science subjects by using the approach of science process skills. Research method used is Classroom Action Research (PTK). The results of this study indicate that science learning by using science process skill approach can improve student learning outcomes of grade IV SDN Pangestu. This is seen based on the number of students who scored above the KKM. In the initial test there were 9 students from 30 students or $30 \%$ complete. In the 1st cycle there are 20 students from 30 students or $67 \%$ complete and in the second cycle there are 28 students or $94 \%$ who scored above the KKM.
\end{abstract}

Keywords: Science learning outcomes, science process skills, elementary school students

\begin{abstract}
ABSTRAK
Penelitian ini dilatarbelakangi karena permasalahan hasil belajar siswa kelas IV SD Negeri Pangestu pada mata pelajaran IPA yang cenderung rendah. Padahal mata pelajaran IPA di sekolah dasar merupakan salah satu mata pelajaran yang tercantum pada kurikulum sekolah dasar. Mata pelajaran IPA juga merupakan mata pelajaran yang wajib diujikan pada saat Ujian Akhir Sekolah (UAS). Pada proses pembelajarannya, untuk mengoptimalkan hasil belajar siswa, maka guru harus mengoptimalkan keterampilan proses sains. Penelitian ini bertujuan untuk mengetahui peningkatan hasil belajar siswa pada mata pelajaran IPA dengan menggunakan pendekatan keterampilan proses sains. Metode penelitian yang digunakan adalah Penelitian Tindakan Kelas (PTK). Hasil penelitian ini menunjukkan bahwa pembelajaran IPA dengan menggunakan pendekatan keterampilan proses sains dapat meningkatkan hasil belajar siswa kelas IV SD Negeri Pangestu. Hal ini terlihat berdasarkan jumlah siswa yang memperoleh nilai di atas KKM. Pada tes awal terdapat 9 siswa dari 30 siswa atau sebesar $30 \%$ yang tuntas. Pada siklus ke-1 terdapat 20 siswa dari 30 siswa atau sebesar $67 \%$
\end{abstract}


yang tuntas dan pada siklus ke-2 terdapat 28 siswa atau sebesar 94\% yang memperoleh nilai di atas KKM.

Kata Kunci: Hasil belajar IPA, keterampilan proses sains, siswa sekolah dasar

\section{A. PENDAHULUAN}

IPA merupakan bidang studi yang berfungsi untuk mempelajari alam semesta dan gejala-gejala alam, dengan tujuan agar siswa dapat memahami dan mengenal alam secara keseluruhan beserta isinya (Trianto, 2013). Pembelajaran IPA identik dengan pengamatan atau observasi dan percobaan. Pada intinya, fokus kajian IPA adalah berbagai peristiwa alam atau kejadian alam yang terdapat di lingkungan siswa. Guru harus mampu membantu siswa agar dapat memahami suatu materi pelajaran dengan cara melibatkan siswa dalam proses pengamatan atau observasi dan mempraktekkan kejadian atau hal-hal yang terdapat dalam materi IPA sesuai dengan kondisi lingkungan kehidupan siswa.

Pada kenyataannya dalam pembelajaran IPA di SD, dijumpai adanya guru yang kurang tepat dalam memilih pendekatan ataupun metode pembelajaran yang sesuai dengan materi. Terkadang metode yang digunakan hanya metode ceramah dan penugasan, guru menjelaskan materi pembelajaran hanya terpaku pada buku teks sebagai satu-satunya sumber belajar, dalam pelaksanaannya kurang melibatkan siswa pada aktivitas kerja ilmiah, sehingga mengakibatkan pembelajaran kurang bervariasi dan kurangnya motivasi siswa saat proses pembelajaran IPA yang berdampak pada hasil belajar siswa yang belum optimal.

Keterampilan Proses Sains atau KPS merupakan salah satu pendekatan yang harus dijadikan acuan guru dalam melaksanakan proses pembelajaran IPA. Menurut Dökme \& Aydınlı (2009) keterampilan proses sains didasarkan pada penyelidikan ilmiah dan terkait dengan keterampilan kognitif dan investigasi. Sejalan dengan yang dikemukakan oleh Çakir \& Sarikaya (2010) bahwa keterampilan proses sains diartikan sebagai kemampuan menggunakan pikiran, nalar dan perbuatan secara efisien dan efektif untuk mencapai suatu hasil tertentu, termasuk kreativitas para ilmuwan dalam bekerja secara ilmiah. Pendekatan keterampilan proses 
sains berarti menekankan pada pembentukan keterampilan memperoleh pengetahuan dan mengkomunikasikan perolehannya. Dengan kata lain, pendekatan keterampilan proses sains dapat menstimulasi perkembangan kognitif, afektif, dan psikomotorik siswa.

Berdasarkan hasil observasi awal yang dilakukan peneliti di SD Negeri Pangestu terhadap hasil ulangan harian pada mata pelajaran IPA kelas IV, masih banyak siswa yang memperoleh nilai di bawah KKM yang telah ditentukan yaitu 70 . Dari 30 siswa hanya 9 atau sebesar $30 \%$ yang telah mencapai KKM dan 21 siswa atau sebesar $70 \%$ belum mencapai KKM. Berdasarkan hasil observasi awal tersebut, perlu adanya perbaikan agar pembelajaran lebih optimal dan mendorong siswa untuk meningkatkan hasil belajarnya. Salah satu alternatif pembelajaran adalah dengan menggunakan pendekatan keterampilan proses sains, sebab dengan menggunakan pendekatan keterampilan proses sains siswa akan terlibat secara langsung dalam proses pembelajaran. Selain itu, dengan menggunakan pendekatan keterampilan proses sains guru berperan sebagai pembimbing, fasilitator, mediator. Dengan kata lain, pembelajaran berpusat pada siswa (student centered).

\section{B. LANDASAN TEORI}

1. Pengertian Keterampilan Proses Sains

Menurut Trianto (2013: 141) cakupan yang terdapat dalam IPA meliputi alam semesta keseluruhan, benda-benda yang ada di permukaan bumi, di dalam perut bumi dan di luar angkasa, baik yang dapat diamati indera maupun yang tidak dapat diamati dengan indera. IPA sebagai proses merupakan kumpulan faktafakta yang saling berhubungan berdasarkan hasil penelitian sehingga menghasilkan produk-produk sains yang dapat diterapkan oleh masyarakat. Widodo dkk (2007: 97) mengemukakan bahwa memahami IPA berarti juga memahami proses IPA, yaitu memahami bagaimana mengumpulkan fakta-fakta dan memahami mengenai bagaimana menghubungkan fakta-fakta untuk menginterpretasikannya. Carin (dalam Samatowa, 2011: 5) mendefinisikan keterampilan proses sebagai kegiatan mengamati, mencoba memahami apa yang 
diamati, dapat mempergunakan pengetahuan baru untuk meramalkan apa yang terjadi, dan menguji kebenaran ramalan-ramalan tersebut. Dari sejumlah pemaparan di atas, dengan kata lain dapat disimpulkan bahwa pembelajaran IPA yang utuh tidak hanya membelajarkan teori, fakta, hukum, prinsip, dan sebagainya, tetapi juga harus menanamkan atau menstimulasi keterampilan proses sains yang melibatkan siswa secara aktif dalam pembelajaran. Hal ini sejalan dengan yang dikemukakan oleh Shahali, Halim, Treagust, Won, \& Chandrasegaran (2015) bahwa siswa membutuhkan keterampilan proses sains karena mereka menggunakan penalaran ilmiah dan pemikiran kritis untuk mengembangkan pemahaman mereka tentang sains. Selain itu, menurut Õ, Ertürk, \& Kaptan, (2010) denganmengaplikasikan keterampilan proses sains, siswa juga sedang dilatih seperti seorang ilmuwan dalam mengidentifikasi dan memecahkan permasalahan.

\section{Klasifikasi Keterampilan Proses} Sains

Cigrik \& Ozkan, (2015) mengemukakan bahwa keterampilan proses sains terdiri dari keterampilan dasar (basic skllis) dan keterampilan terintegrasi (integrated skills). Funk (dalam Bundu, 2006: 25) menyatakan bahwa keterampilan dasar terdiri dari enam keterampilan yang harus dimiliki, yaitu melakukan observasi, mengklasifikasi, dapat memprediksi, dapat mengukur, menyimpulkan, dan mengkomunikasikan. Sedangkan keterampilan terintegrasi terdiri sepuluh keterampilan, yaitu mengidentifikasi variabel, membuat tabulasi data, menyajikan data dalam bentuk grafik, menggambarkan hubungan dari berbagai variabel, mengumpulkan dan mengolah data, menganalisa penelitian, menyusun hipotesis, mendefinisikan variabel secara operasional, merancang penelitian, dan melaksanakan eksperimen.

Secara keseluruhan, menurut Kruea-in \& Thongperm (2014) keterampilan proses sains terdiri dari keterampilan untuk mengamati, mampu mengklasifikasi, mengukur, menggunakan angka, hubungan ruang/waktu, menyimpulkan, memprediksi, mengkomunikasikan, mengendalikan berbagai variabel, mendefinisikan variabel secara operasional, merumuskan hipotesis, 
bereksperimen, menafsirkan data dan menarik kesimpulan.

\section{Kelebihan dan Kekurangan}

\section{Keterampilan Proses Sains}

Menurut Dimyati \& Mudjiono (2009: 74), kelebihan keterampilan proses sains yaitu: (1) Dapat memberikan rangsangan ilmu pengetahuan, sehingga siswa dapat memahami fakta dan konsep ilmu pengetahuan dengan baik; (2) Memberikan kesempatan kepada siswa bekerja dengan ilmu pengetahuan, tidak sekedar menceritakan atau mendengarkan cerita tentang ilmu pengetahuan. Hal ini menyebabkan siswa menjadi lebih aktif; (3) Membuat siswa menjadi belajar proses dan produk ilmu pengetahuan sekaligus.

Kekurangan keterampilan proses sains menurut Dimyati \& Mudjiono (2009: 75) yaitu: (1) Memerlukan cukup banyak waktu sehingga sulit untuk dapat menyesuaikan bahan pengajaran yang ditetapkan dalam kurikulum; (2) Memerlukan fasilitas yang cukup baik dan lengkap sehingga tidak semua sekolah dapat menyediakannya; (3) Merumuskan masalah, menyusun hipotesis, merancang suatu percobaan untuk memperoleh data yang relevan adalah pekerjaan yang relatif tidak mudah, tidak setiap siswa mampu melaksanakannya.

\section{METODE PENELITIAN}

Penelitian ini dilaksanakan di Sekolah Dasar Negeri Pangestu Kecamatan Sukalarang Kabupaten Sukabumi Tahun Ajaran 2016/2017. Adapun subjek penelitian adalah siswa kelas IV dengan jumlah 30 siswa. Jumlah siswa laki-laki 12 orang dan siswa perempuan 18 orang. Penelitian dilakukan untuk meningkatkan hasil belajar siswa pelajaran IPA dengan penggunaan pendekatan keterampilan proses sains dalam pembelajarannya.

Metode penelitian yang digunakan dalam penelitian ini adalah penelitian tindakan kelas. Menurut Mc. Niff (dalam Asrori, 2012: 4) penelitian tindakan kelas merupakan bentuk penelitian reflektif yang dilakukan oleh guru sendiri yang hasilnya dapat dimanfaatkan sebagai alat untuk mengembangkan dan perbaikan pelajaran. Menurut Lewin (dalam Kunandar, 2008: 42) penelitian tindakan kelas adalah suatu rangkaian langkah yang terdiri atas empat tahap, yakni perencanaan, tindakan, pengamatan, 
dan observasi. Berikut adalah desain PTK menurut Kemmis dan Mc. Taggart:

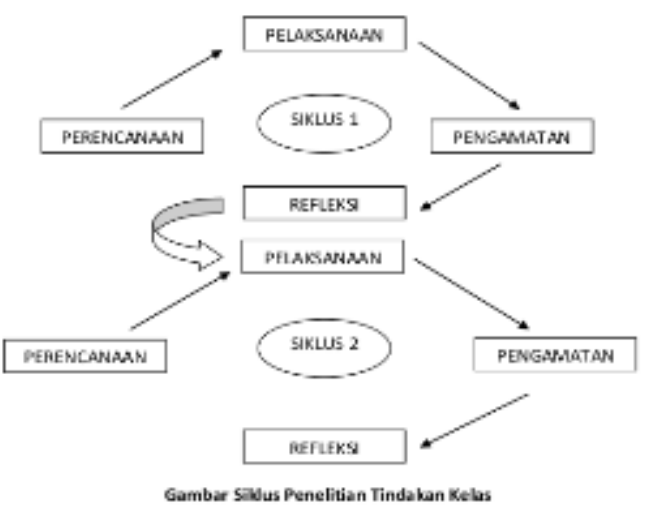

Gambar 1 Desain PTK Kemmis dan MC. Taggart

Teknik pengumpulan data dalam penelitian adalah dengan menggunakan metode observasi dan tes. Data yang diperoleh kemudian dianalisis secara kualitatif dan kuantitatif. Data kualitatif dinyatakan dalam bentuk kata-kata atau simbolsimbol, sedangkan kuantitatif adalah data yang berbentuk angka. Instrumen penelitian yang digunakan berupa lembar tes soal materi gaya dan lembar observasi perencanaan pembelajaran serta pelaksanaan pembelajaran.

\section{HASIL DAN PEMBAHASAN}

Penelitian tindakan kelas ini dilaksanakan sebanyak dua siklus, yaitu siklus ke-1 dan siklus ke-2, dan bersifat memperbaiki pada setiap siklus sebelumnya. Sebelum melaksanakan tindakan pada siklus ke-1, peneliti terlebih dahulu melakukan pengamatan atau observasi awal terhadap guru dan siswa serta hasil belajar pada pembelajaran IPA. Hasil observasi awal akan digunakan sebagai pedoman untuk menyusun rencana pada penelitian.

Penerapan keterampilan proses sains terhadap pembelajaran IPA kelas IV SD Negeri Pangestu, mengalami peningkatan disetiap siklusnya. Dari perolehan hasil pelaksanaan tindakan pada siklus ke1 dan siklus ke-2 telah menunjukkan adanya perbaikan, baik dalam hal perencanaan, pelaksanaan, serta hasil belajar siswa yang meningkat.

Berdasarkan data yang diperoleh terkait dengan perencanaan pembelajaran, ada beberapa hal yang harus diperhatikan dalam perencanaan pembelajaran yang akan dilaksanakan, diantaranya yang berkaitan dengan bahan ajar yang digunakan. Bahan ajar yang lebih menarik akan memberikan pembelajaran lebih bervariasi, sehingga pembelajaran lebih menarik dan minat belajar siswa lebih tinggi serta tidak membuat siswa merasa 
bosan ataupun jenuh. Materi ajar pun harus benar-benar dikembangkan agar bermanfaat dan memberi kemudahan bagi siswa dalam memahami pelajaran. Selain itu, dari segi pengalokasian waktu juga harus diperhatikan mengingat penggunaan pendekatan keterampilan proses sains dalam pembelajaran akan memerlukan waktu yang relatif panjang untuk melakukan persiapan yang matang, karena tanpa persiapan yang matang dapat menyebabkan kegagalan yang berakibatkan pada ketidakefektifan pembelajaran. Hal tersebut akan berdampak pada hasil belajar yang dicapai.

Pelaksanaan pembelajaran IPA dengan menggunakan pendekatan keterampilan proses sains di SD Negeri Pangestu, dalam pelaksanaannya begitu membantu siswa dalam memahami pelajaran. Pada siklus ke-1 pengelolaan proses pembelajaran dengan menggunakan pendekatan keterampilan proses sains belum sepenuhya berjalan dengan baik, karena pada saat pembelajaran berlangsung peneliti belum mampu mengkondisikan siswa pada saat diskusi kelompok, siswa belum menunjukkan kekompakan dalam kelompoknya. Hal tersebut disebabkan karena siswa masih belum terbiasa dengan metode pembelajaran yang diterapkan oleh peneliti.

Pada tindakan siklus ke-2, peneliti berusaha memperbaiki kekurangan yang ada berdasarkan hasil refleksi dari siklus ke-1. Pada pembelajaran siklus ke-2 peneliti lebih maksimal dalam melaksanakan pembelajaran, peneliti lebih bisa mengkondisikan kelas dengan baik dalam pembelajaran kelompok, siswa lebih fokus dalam mengikuti pembelajaran dan siswa lebih menunjukkan kekompakannya dalam diskusi kelompok, sehingga pembelajaran semakin efektif. Hasil penilaian pelaksanaan pembelajaran dari setiap siklusnya mengalami peningkatan, sehingga hasil belajar yang diperoleh siswa dalam pembelajaran IPA mengalami peningkatan dari tahap peneliti melakukan observasi awal hingga melakukan tindakan pada siklus ke-1 dan siklus ke-2. Peningkatan tersebut dapat dilihat dari persentase ketuntasan hasil belajar yang diperoleh siswa kelas IV SD Negeri Pangestu. 
Berikut tabel yang dapat memperjelas mengenai hasil observasi baik dalam perencanaan maupun pelaksanaan pembelajaran dan hasil belajar siswa pada siklus ke-1 dan siklus ke-2.

Tabel 1

Hasil Perencanaan Pembelajaran SD Negeri

\begin{tabular}{|c|c|c|}
\multicolumn{3}{c|}{ Pangestu } \\
& $\begin{array}{c}\text { Hasil } \\
\text { Perencanaan } \\
\text { Pembelajaran }\end{array}$ & $\begin{array}{c}\text { Kriteria } \\
\text { Penilaian }\end{array}$ \\
\hline 1 & $80 \%$ & Baik \\
\hline 2 & $93 \%$ & Sangat Baik \\
\hline
\end{tabular}

Tabel 2

Hasil Pelaksanaan Pembelajaran SD Negeri Pangestu

\begin{tabular}{|c|c|c|}
\hline Siklus & $\begin{array}{c}\text { Hasil } \\
\text { Pelaksanaan } \\
\text { Pembelajaran }\end{array}$ & $\begin{array}{c}\text { Kriteria } \\
\text { Penilaian }\end{array}$ \\
\hline 1 & $83 \%$ & Baik \\
\hline 2 & $95 \%$ & Sangat Baik \\
\hline
\end{tabular}

Tabel 3

Ketercapaian Hasil Belajar Siswa SD Negeri Pangestu

\begin{tabular}{|l|c|c|c|}
\hline Pencapaian & $\begin{array}{c}\text { Observasi } \\
\text { Awal }\end{array}$ & $\begin{array}{c}\text { Siklus } \\
1\end{array}$ & $\begin{array}{c}\text { Siklus } \\
2\end{array}$ \\
\hline $\begin{array}{l}\text { Nilai Rata- } \\
\text { Rata }\end{array}$ & 67 & 79 & 88 \\
\hline Tuntas & $30 \%$ & $67 \%$ & $94 \%$ \\
\hline $\begin{array}{l}\text { Belum } \\
\text { Tuntas }\end{array}$ & $70 \%$ & $33 \%$ & $6 \%$ \\
\hline
\end{tabular}

\section{E. KESIMPULAN}

Berdasarkan hasil penelitian yang telah dilaksanakan pada siswa kelas IV di SD Negeri Pangesth, maka dapat disimpulkan sebagai berikut: pertama, kemampuan peneliti dalam membuat perencanaan pembelajaran dengan menggunakan pendekatan keterampilan proses mengalami peningkatan dalam setiap siklusnya. Hasil yang dicapai pada siklus ke-1 yaitu sebesar $80 \%$ dengan kriteria penilaian baik, dan pada siklus ke-2 meningkat menjadi $93 \%$ dengan kriteria penilaian sangat baik.

Kedua, hasil dari kemampuan peneliti dalam proses pengelolaan pelaksanaan kegiatan pembelajaran mengalami peningkatan pada setiap siklusnya. Siklus ke-1 mencapai nilai $83 \%$ dan pada siklus ke-2 menjadi 95\%. Kriteria penilaian yang dicapai pada siklus ke-1 mendapat kriteria penilaian baik dan pada siklus ke-2 meningkat dengan kriteria penilaian sangat baik.

Ketiga, hasil belajar siswa meningkat setiap siklusnya, pada observasi awal sebelum dilakukan tindakan, nilai rata-rata hasil belajar siswa di SD Negeri Pangestu sebesar 67, dengan ketercapaian ketuntasan hasil belajar $30 \%$. Terjadi peningkatan pada siklus ke-1 dengan nilai rata-rata hasil belajar sebesar 79 dengan ketercapaian ketuntasan hasil belajar $67 \%$, dan kembali 
mengalami peningkatan pada siklus ke-2 dengan nilai rata-rata hasil belajar sebesar 88, dengan ketercapaian ketuntasan hasil belajar 94\% dari jumlah siswa yang mencapai nilai KKM.

Dengan demikian penerapan pendekatan keterampilan proses selain telah berhasil meningkatkan hasil belajar siswa pada pembelajaran IPA dengan nilai KKM 70, juga dapat meningkatkan kinerja guru yang mengajar (peneliti) dalam merencanakan hingga pelaksanaan pembelajaran berlangsung.

Berdasarkan hasil penelitian dan kesimpulan, peneliti memiliki beberapa saran yang diharapkan dapat membangun dan mendukung peningkatan mutu pendidikan, yaitu sebagai berikut:

1. Bagi kepala sekolah, untuk meningkatkan mutu pendidikan di sekolah, hendaknya memberikan rekomendasi bagi para guru agar dapat mengembangkan pelaksanaan pembelajaran IPA dengan menggunakan pendekatan keterampilan proses sains dalam upaya meningkatkan hasil belajar siswa serta memberikan dukungan dan partisipasinya, sehingga pembelajaran di sekolah dapat berjalan sesuai harapan.

2. Bagi guru, sebaiknya penggunaan pendekatan keterampilan proses sains bukan hanya diterapkan pada beberapa materi IPA saja, tetapi dapat diterapkan pada hampir semua materi IPA, karena terbukti dengan penggunaan pendekatan keterampilan proses sains dapat meningkatkan hasil belajar siswa.

3. Bagi siswa, hendaknya harus lebih aktif dalam mengikuti kegiatan pembelajaran serta diharapkan mampu mengaktualisasikan pengalaman belajar yang diperolehnya dalam kehidupan sehari-hari.

4. Bagi peneliti selanjutnya, hendaknya dapat mengembangkan pengetahuan penelitian yang lebih luas lagi, terutama yang berkaitan dengan siswa yang menjadi subjek penelitian, hal tersebut dimaksudkan agar siswa mudah memahami dan mengerti pelajaran dengan baik, sehingga hasil belajar siswa akan meningkat serta menambah wawasan yang lebih luas. 


\section{DAFTAR PUSTAKA}

Asrori, M. (2012). Penelitian tindakan kelas. Bandung: CV Wacana Prima.

Bundu, P. (2006). Penilaian keterampilan proses dan sikap ilmiah dalam pembelajaran sains sd. Jakarta: Depdiknas.

Çakir, N. K., \& Sarikaya, M. (2010). An evaluation of science process skills of the Science Teaching majors. Procedia - Social and Behavioral Sciences, 9, 15921596.

Cigrik, E., \& Ozkan, M. (2015). The Investigation of The Effect of Visiting Science Center on Scientific Process Skills. Procedia - Social and Behavioral Sciences, 197(February), 13121316.

Dimyati \& Mudjiono. (2009). Belajar dan pembelajaran. Jakarta: PT. Rineka Cipta.

Dökme, İ., \& Aydınlı, E. (2009). Turkish primary school students' performance on basic science process skills. Procedia - Social and Behavioral Sciences, 1(1), 544-548.

Kruea-in, N., \& Thongperm, O. (2014). Teaching of Science Process Skills in Thai Contexts: Status, Supports and Obstacles. Procedia - Social and Behavioral Sciences, 141, 1324-1329.

Kunandar. (2008). Langkah mudah penelitan tindakan kelas sebagai pengembangan profesi guru. Jakarta: PT Rajagrafindo Persada.

Õ, K. B., Ertürk, G., \& Kaptan, F. (2010). The awareness levels of pre-school education teachers regarding science process skills, 2, 1993-1999.
Samatowa, U. (2011). Pembelajaran ipa di sekolah dasar. Jakarta: Indeks.

Shahali, E. H. M., Halim, L., Treagust, D. F., Won, M., \& Chandrasegaran, A. L. (2015). Primary School Teachers Understanding of Science Process Skills in Relation to Their Teaching Qualifications and Teaching Experience.

Trianto. (2013). Model pembelajaran terpadu. Jakarta: PT Bumi Aksara.

Widodo, dkk. (2007). Pendidikan ipa di sd. Bandung: UPI Press. 